\title{
A study on intima- media thickness of carotid artery in children with nephrotic syndrome: a cross sectional study
}

\author{
Chaubey $\mathbf{S}^{1}$, Singh Vijay $K^{2}$, Singh $\mathbf{P}^{3}$, Mittal $\mathbf{M}^{4}$, Singh Abhishek K ${ }^{5}$, Kushwaha K.P ${ }^{6}$. \\ ${ }^{1}$ Dr. Satish Chaubey, Senior Resident, ${ }^{2}$ Dr. Vijay Kumar Singh, Assistant Professor, ${ }^{3}$ Dr. Priyanka Singh, Assistant \\ Professor, ${ }^{4}$ Dr. Mahima Mittal, Associate Professor, ${ }^{5}$ Dr. Abhishek Kumar Singh, Assistant Professor, ${ }^{6}$ Dr. K.P. \\ Kushwaha Ex. Professor, all authors are affiliated with Department of Pediatrics, BRD Medical College, Gorakhpur \\ (U.P.), India.
}

Address for Correspondence: Dr. Vijay Kumar Singh, Assistant Professor, Department of Pediatrics, BRD Medical College, Gorakhpur, UP, India. Email id: vijaysingh.vns.04@gmail.com

\begin{abstract}
Introduction: Atherosclerosis is one of the complications of Nephrotic syndrome. It is due to frequent exposure to hyperlipidemia, hypertension, and hypoproteinemia, steroid and immunosuppressive therapy may also contribute to the risk for cardiovascular diseases. Objective: To evaluate intima- media thickness of carotid artery in children with nephrotic syndrome. Design: A cross sectional study. Setting: The study was done in Nehru hospital of B.R.D Medical College Gorakhpur (U.P.) from June 2014- March 2015. Material \& Methods: Total 150 children divided in to study group $(\mathrm{n} 1=50)$ and control group II $(\mathrm{n} 2=100)$. $(\mathrm{n} 1=50)$ children with history of nephrotic syndrome enrolled in this study. The Inclusion criteria were nephrotic syndrome with normal serum complement, being on therapy for nephrotic syndrome (continuous or interrupted) for at least one year, glomerular filtration rate more than $90 \mathrm{ml} / \mathrm{min} / 1.73 \mathrm{~m}{ }^{2}$ and age above two years at the time of study. (N2=100) healthy age, sex weight, height and RBS matched children considered as control group. The cIMT was evaluated in nephrotic children. Chi square test was used to test difference among study and control groups. A P value less than 0.05 was considered statistically significant. Result: In the study group $(\mathrm{n} 1=50)$ steroid resistant, steroid dependent, steroid sensitive and infrequent relapse nephrotic syndrome included one-fourth each. The mean cIMT $(\mathrm{mm})$ in nephrotic children was $0.42( \pm 0.14)$ while mean cIMT in control was 0.34 $( \pm 0.06)$ and $(\mathrm{p}<0.0014)$. Subsequently, the factor that influenced on thickness of cIMT were BMI, SBP, DBP, Total cholesterol, VLDL, LDL, TGs, serum protein $((\mathrm{p}<0.05)$ and duration of disease $(\mathrm{r}=0.83)$. Conclusion: cIMT was thicker in nephrotic children, were influenced by the factor that increases thickness of cIMT were hyperlipidemia, hypertension, hypoproteinemia and duration of disease.
\end{abstract}

Keywords: cIMT, Hyperlipidemia, Hypertension, Hypoproteinemia, Nephrotic syndrome

\section{Introduction}

Nephrotic syndrome may be defined as heavy proteinuria that is severe enough to cause hypoalbuminemia, hypercholesterolemia and usually edema. Proteinuria of any magnitude has been identified as a risk factor for cardiovascular diseases in adults [1]. In some patients, factors as hypertension, renal insufficiency, and steroid therapy may also contribute to the risk for cardiovascular diseases [2]. Severe disorder of lipid metabolism is associated with an enhanced risk to develop cardiovascular risk factors

Manuscript received: $14^{\text {th }}$ December 2016

Reviewed: $20^{\text {th }}$ December 2016

Author Corrected: $29^{\text {th }}$ December 2016

Accepted for Publication: $5^{\text {th }}$ January 2017 later in life with atherosclerotic lesions beginning already in Childhood [3].

Carotid intima-media thickness (cIMT) is an indirect marker of atherosclerosis and target organ damage in adults [4,5]. Its value in children is still under debate but there are increasing numbers of studies among children with risk factor for vascular damage [6]. A recent systematic review has reported moderate correlation between cIMT and coronary atherosclerosis or cardiovascular events [7, 8]. Hemodynamic, metabolic, and inflammatory factors change reversibly the arterial wall thickness. Impaired function of endothelium has been shown in acute phase of 
idiopathic nephrotic syndrome $[9,10]$ Nephrotic patients are prone to myocardial infarction and coronary artery disease secondary to hypoalbuminemia, dyslipidemia, and hypercoagulopathy state $[10,11]$. Few studies of cIMT in nephrotic children show to be correlated with duration of disease and unresponsiveness to steroid; however, none of them investigates carotid function including distensibility, stiffness, and elasticity [12, 13]. In this study cIMT was evaluated as an atherosclerosis surrogate marker in children with nephrotic syndrome.

Atherosclerosis may develop when deposits of cholesterol and plaque accumulate at a tear in the inner lining of an artery. As the deposits harden and occlude the arterial lumen, blood flow to distant tissues decreases and a clot may become lodged, completely blocking the artery. Raised LDL-cholesterol is main cause for development of atherosclerosis [14]

B-mode ultrasound is a non-invasive technique used to measure atherosclerosis in superficial arteries. Carotid intima-media thickness can be measured by using Bmode ultrasound as well. Increase in cIMT is associated with increased risk of coronary artery diseases. The method is sensitive enough to be applied in clinical studies for progress or regress. cIMT can also be used as therapeutic end point $[15,16]$.

Measurement of cIMT progression has enabled clinicians to decide about the use of aggressive treatment in primary prevention of atherosclerotic diseases [17]. Measurement of cIMT is thus a convenient method to determine atherosclerosis and address consequences such as coronary artery diseases and stroke. It is a biomarker of arterial wall thickening and stiffening [18, 19]. cIMT is widely used in observational studies to predict consequences of atherosclerosis [20,21].

\section{Selection of Patients}

\section{Inclusion criteria}

1) Nephrotic syndrome with normal serum complement.

2) Being on therapy for nephrotic syndrome (continuous or interrupted) for at least one year.

3) Glomerular filtration rate more than $90 \mathrm{ml} / \mathrm{min} / 1.73 \mathrm{~m}^{2}$.

4) Age above two years at the time of study.

\section{Exclusion criteria}

1) Patients having history of familial hypercholesterolemia.

2) Known case of essential hypertension.

3) Known case of Type-1 diabetes mellitus.
The aim of this study was to compare cIMT of patients with nephrotic syndrome with normal controls and to establish if this can be used to determine the extent, severity and rate of progression of atherosclerosis while correlating it to raised total cholesterol and LDLcholesterol. Its application can thus also facilitate assessing the efficacy of a given therapy.

\section{Aims \& Objectives}

1) To study the Carotid intimal-medial thickness in children with nephrotic syndrome.

2) Correlation of cIMT with Dyslipidemia in nephrotic syndrome.

Ethical issues: The study was performed in accordance with the ethical standards laid down in the 1964 Declaration of Helsinki revised in Tokyo 2008. It was approved by ethical committee of B. R. D. Medical College, Gorakhpur. Written consent was taken from patient's parent by explaining them nature and purpose of study in their language.

\section{Material \& methods}

The study was done in Nehru hospital of B.R.D Medical College Gorakhpur (U.P.) from June 2014- March 2015.

Statistical analysis: statistical analysis was done by using SPSS-21 software. sociodemographic and clinical characteristics were described using counts and proportions for categorical variables and mean and standard deviation for numerical variables. Chi square test was used to test difference among case and control groups. A P value less than 0.05 was considered statistically significant. 
The children who fulfill the inclusion criteria considered as study group I $(\mathrm{n} 1=50)$ were taken as cases while children with history of minor non-renal illness who attended outpatient clinic were kept in controls group II (n2=100) children of control groups were matched (age, sex weight, height and Random blood sugar) [table-1]. Familial hypercholesterolemia was clinically diagnosed by premature coronary diseases, tendon xanthomas, arcuscornealis and family history of premature coronary heart diseases.

A working proforma containing informed consent was filled containing detail present history, past history and drug history was taken. Weight, height, and blood pressure were recorded. General and systemic examination was done thoroughly. After maintaining aseptic condition blood and urine sample of both groups were collected for biochemical tests (lipid profile, serum electrolyte, serum protein, serum urea serum creatinine and serum complement level) tests were done in college central lab. After that children of group and group II were send to department of radiology for measurement of cIMT.

The Carotid intima-media thickness (cIMT) was measured as the following way: cIMT of the common carotid artery on each side was measured using $7.5 \mathrm{mhz}$ linear and $7.5 \mathrm{mhz}$ convex probes. The cIMT is defined as the distance between the first (lumen-intima interface) and the second (media-adventitia interface) echogenic line of the far wall, using a manual cursor placement measurement technique.

The double-line pattern was visualised by 2D- echo on both walls of the common carotid artery (CCA) in a longitudinal view. Two parallel lines (leading edges of two anatomical boundaries) form it as shown in figure below:

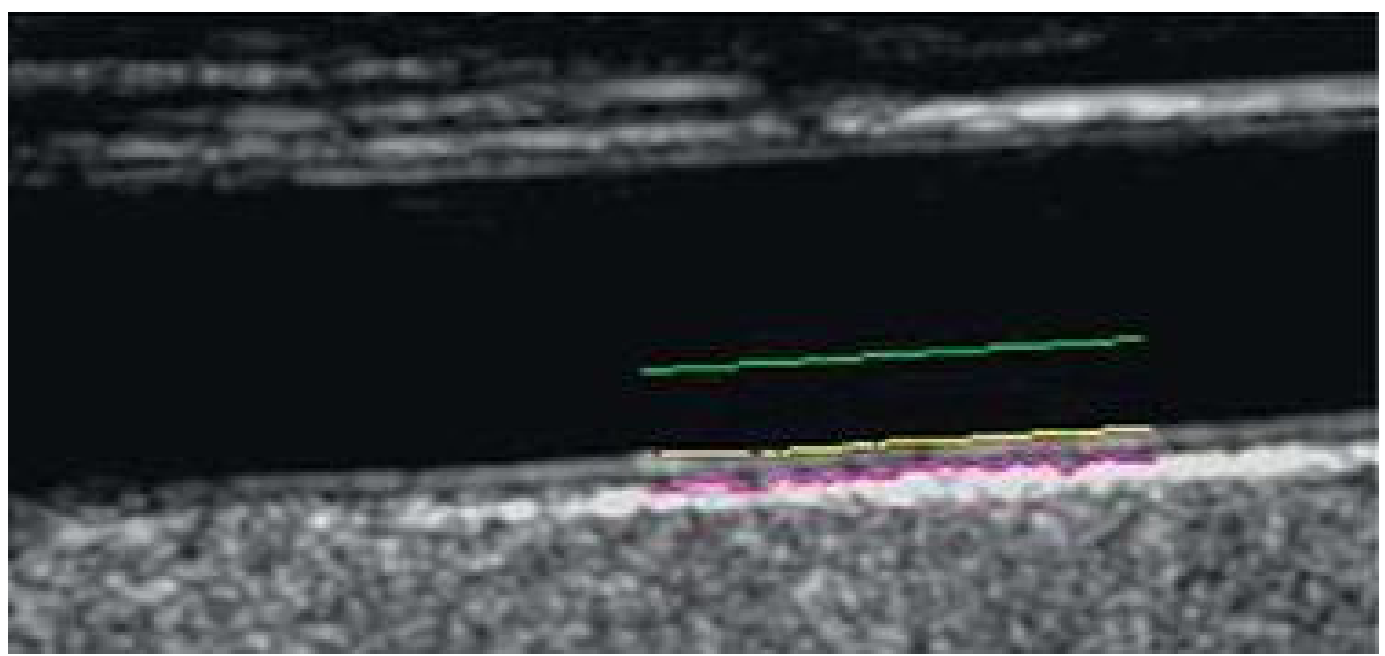

[Intima-media thickness (IMT) definition - IMT is measured as the distance between lumen-intima (yellow line) and media-adventitia (pink line) interfaces.]

cIMT was measured as per guidelines decided by-

a) The European guidelines on cardiovascular disease prevention in clinical practice :(2012).[23]

b) The European Society of Cardiology (ESC) / European Society of Hypertension (ESH) guidelines (2013).[24]

c) The American Society of Echocardiography (ASE) (2012); Framingham Risk Score[26]

d) The ACC/AHA guidelines on the assessment of cardiovascular risk (2013)[26,26]

High resolution B-mode system was used equipped with a linear array transducer $7.5 \mathrm{~Hz}$ and footprint of $3 \mathrm{~cm}$. Focus depth was $35 \mathrm{~cm}$, frame rate $20 \mathrm{~Hz}$ and gain setting was adjusted optimally to facilitate edge detection.

Carotid bifurcation in the image was used as a landmark to provide accurate measurement. cIMT was measured along a segment of the artery free of atherosclerotic plaque with clearly defined lumen-intima and media-adventitia interfaces as shown in figure: 


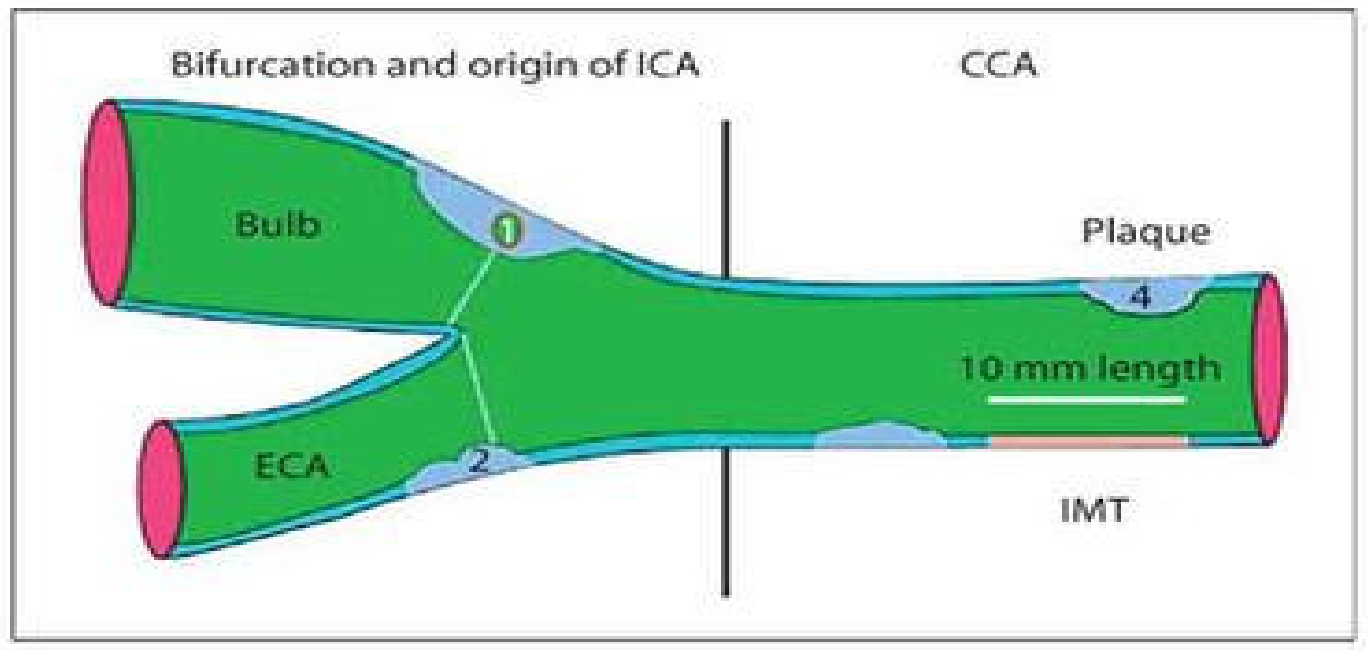

Proper location for cIMT measurement: Far wall of the common carotid artery was used to measure cIMT [29]. Arterial wall segments were assessed longitudinally and perpendicular to the ultrasound beam. cIMT was measured at a distance of $5 \mathrm{~mm}$ below common carotid artery bifurcation in both the right and left sides. The examination was performed at supine position with a slightly overextended neck after 10 minutes of rest. Two measurements were made on each side, and the mean value was calculated separately for each common carotid artery. Right cIMT value and left cIMT value were averaged because there is increased reproducibility of cIMT measurement when values from right and left CCA are combined [30]. cIMT was measured at end diastole. Images of good quality were taken to further analysis. The radiologist was not aware of the clinical data of the patient both groups. After that data were collected and analyzed.

Blood pressure levels (systolic or diastolic) of children below $90^{\text {th }}$ percentile for age and sex were considered normotensive. Blood pressure values between 90 and $95^{\text {th }}$ percentile were considered prehypertensive and systolic or diastolic blood pressure above $95^{\text {th }}$ percentile for age and sex confirmed on at least two occasions were considered hypertensive $[24,25]$.

Patients were classified according to the following definitions of nephrotic syndrome: Remission: Protein free urine (urine protein negative or trace; or $<4 \mathrm{mg} / \mathrm{m}^{2} /$ hour) for three consecutive days; Relapse: Proteinuria (urine protein 3+ or more) for three consecutive days, Infrequent relapse: Responders but with 3 or less relapses within one year, Frequent relapse: Relapsers who have 2 or more relapses within 6 months of the initial episode; or more than 3 relapses in any 12 months period, Steroid dependent: Occurrence of two consecutive relapses during alternate day steroid therapy or within 2 weeks of its discontinuation; Steroid resistant: Absence of remission despite therapy with daily prednisolone at a dose of $2 \mathrm{mg} / \mathrm{kg} /$ day for four weeks [22,23].

Limitation of this study: Small sample size and low power of the study.

\section{Result}

After analyzing data showed that the age distribution in both groups differences found to be insignificant $(\mathrm{p}<0.05)$, sex distribution in study group out of 50 cases, $30(60 \%)$ were male and $20(40 \%)$ were female. The number of male children was more than the female children [31] and other characteristics like mean of weight, height, serum random blood sugar, differences between study group I and control group II found to be insignificant ( $p>0.05$ ) [ Table-1].

But when analyzing body mass index, systolic BP, diastolic BP, total serum cholesterol, HDL cholesterol, LDLcholesterol, VLDLcholesterol, triglyceride, serum protein, albumin and carotid intima-media thickness, their differences between study group I and control group II found to be significant ( $\mathrm{p}<0.05$ [Table 1].

Graphs (A-F) showing there was significant positive correlation between total serum cholesterol, LDL cholesterol, serum triglyceride, duration of disease, $\mathrm{BP}$ and $\mathrm{DBP}$ and cIMT respectively. 
Table-1: Demographic profile of patients.

\begin{tabular}{|c|c|c|c|}
\hline Characteristics & Study Group I(n1 =50) & Controls Group II (n2=100) & P-value \\
\hline $2-6 y r s$ & 33 & 66 & \multirow[t]{2}{*}{1.000} \\
\hline 6-13yrs & 17 & 34 & \\
\hline Male $(\%)$ & 30 & 60 & 60 \\
\hline Female $(\%)$ & 20 & 40 & 40 \\
\hline Weight(kg), mean (SD) & $24.52(7.72)$ & $23.12(7.49)$ & 0.548 \\
\hline Height $(\mathrm{cm})$, Mean(SD) & $118.65(15.7)$ & $120.6(15.96)$ & 0.690 \\
\hline RBS(mg/dl), mean (SD & $94.23(10.52)$ & $91.23(11.71)$ & 0.441 \\
\hline BMI (kg/m2), mean (SD) & $17.71(1.7)$ & $16.49(1.64)$ & 0.0303 \\
\hline SBP $(\mathrm{mmHg})$, mean (SD) & $110.08(10.49)$ & $104.08(8.27)$ & 0.0117 \\
\hline DBP (mmHg), mean (SD) & $89.85(13.51)$ & $80.42(9.22)$ & 0.011 \\
\hline TSCh, mean (SD) & $416.80(99)$ & $166.19(10.94)$ & 0.0001 \\
\hline HDL ch,mean (SD) & $50.38(13.05)$ & $58.01(7.17)$ & 0.0025 \\
\hline VLDL ch, mean (SD) & $66.38(24.34)$ & $28.7(8.94)$ & 0.0001 \\
\hline LDL, mean (SD) & $320.42(79.24)$ & $79.51(10.37)$ & 0.0001 \\
\hline SERUM TG, mean (SD) & $323.80(75.45)$ & $72.79(10.25)$ & 0.0001 \\
\hline $\begin{array}{l}\text { SERUM PROTEIN (mg/dl), } \\
\text { mean (SD) }\end{array}$ & $5.73(0.49)$ & $6.98(0.63)$ & 0.0001 \\
\hline $\begin{array}{l}\text { SERUM ALBUMIN (mg/dl), } \\
\text { mean (SD) }\end{array}$ & $2.21(0.24)$ & $4.06(0.60)$ & 0.0001 \\
\hline Avg. cIMT (mm), mean (SD) & $0.42(0.1027)$ & $0.34(0.0422)$ & 0.0014 \\
\hline
\end{tabular}

\section{Graphs: showing correlation}

\section{CORRELATION BETWEEN TOTAL SERUM CHOLESTEROL AND cIMT}

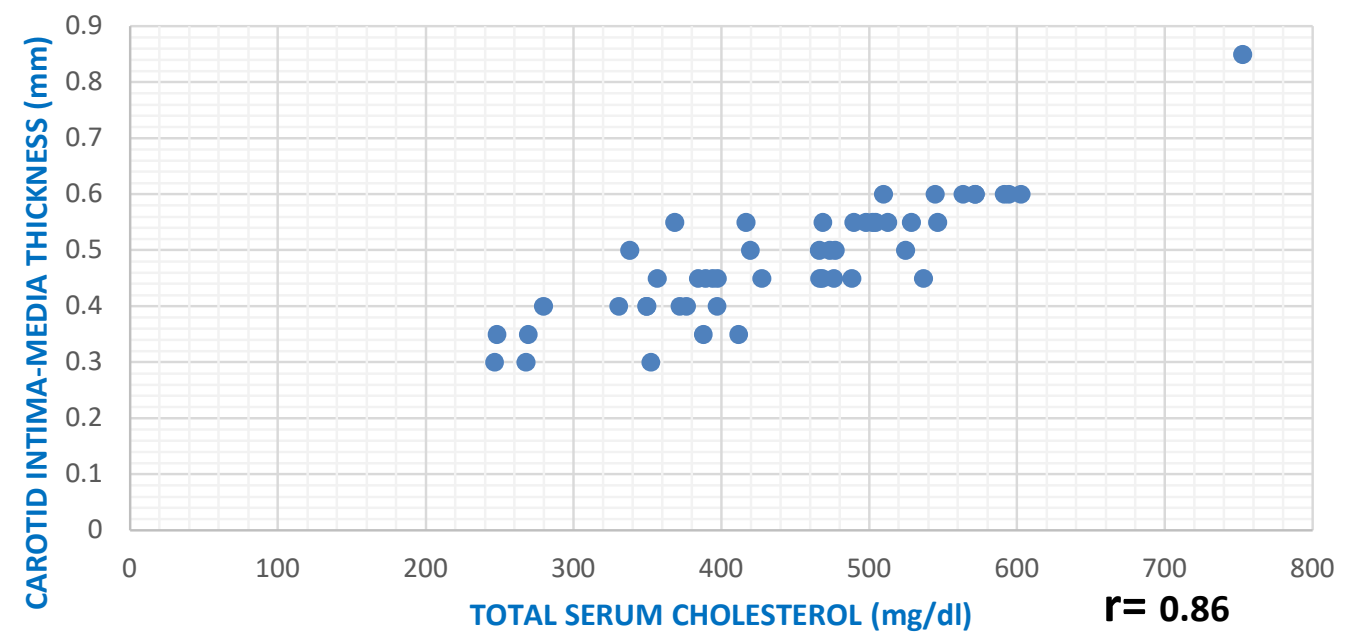

(A) 


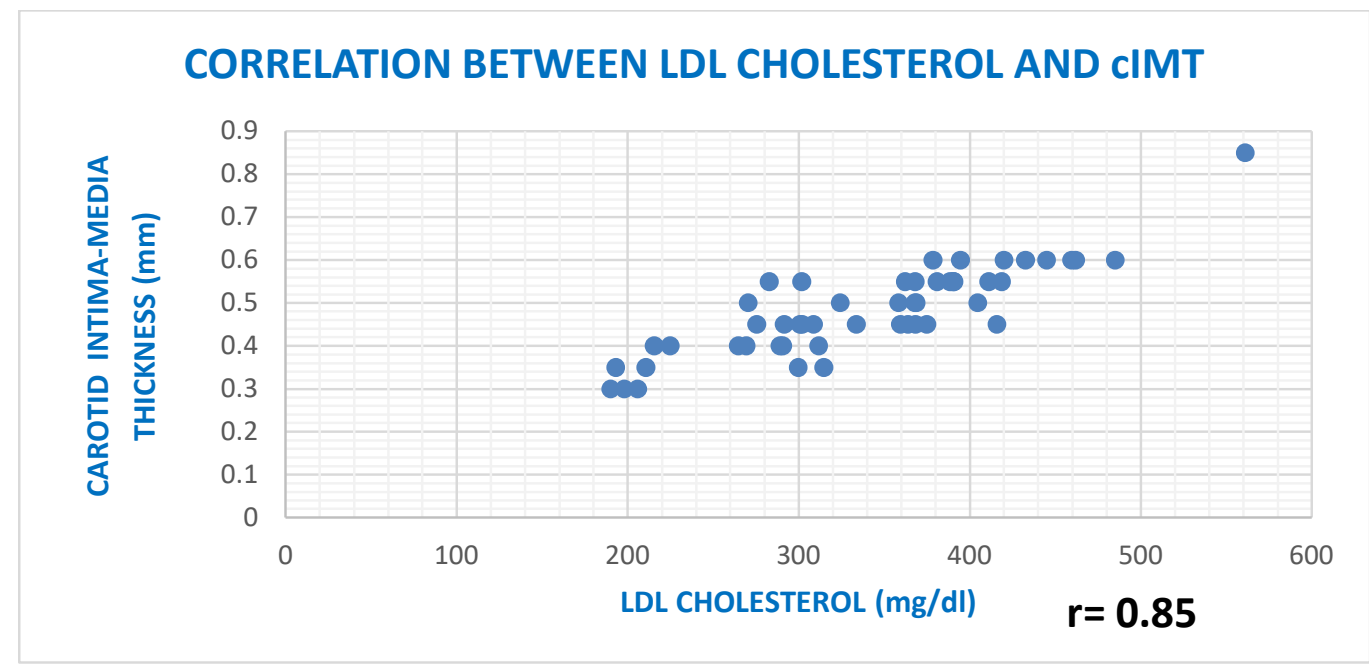

(B)

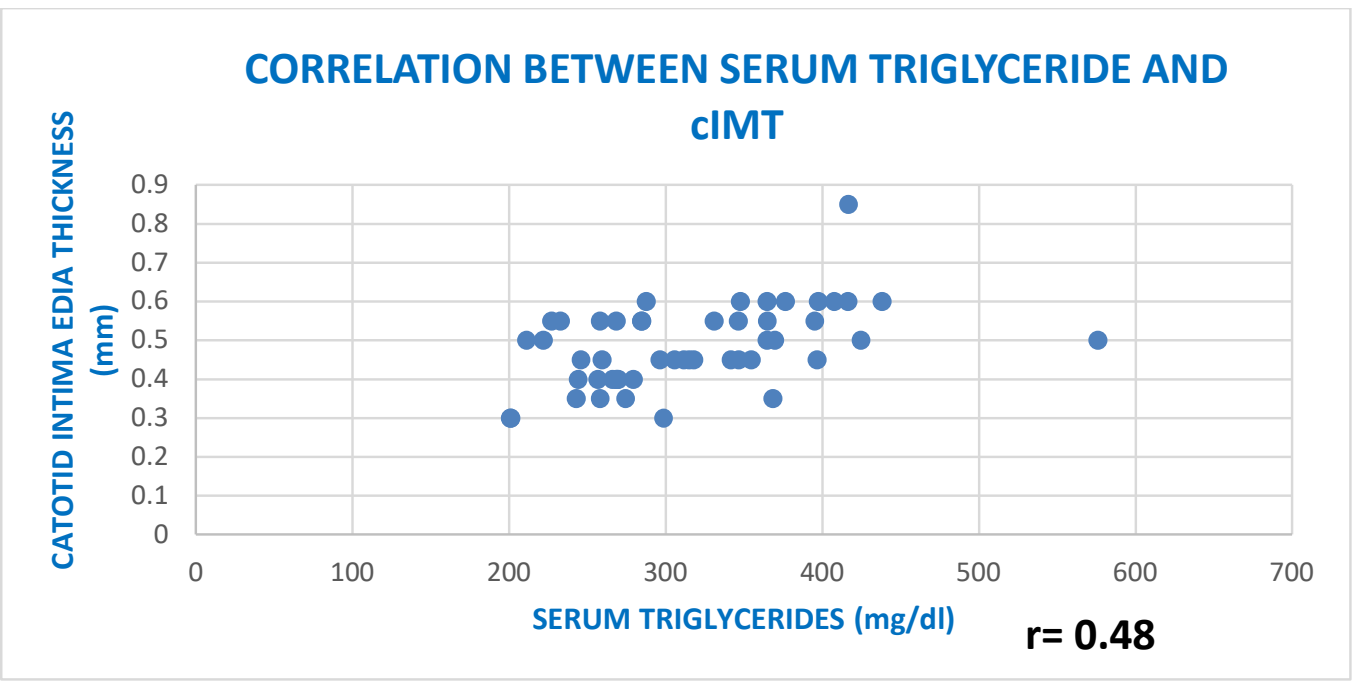

(C)

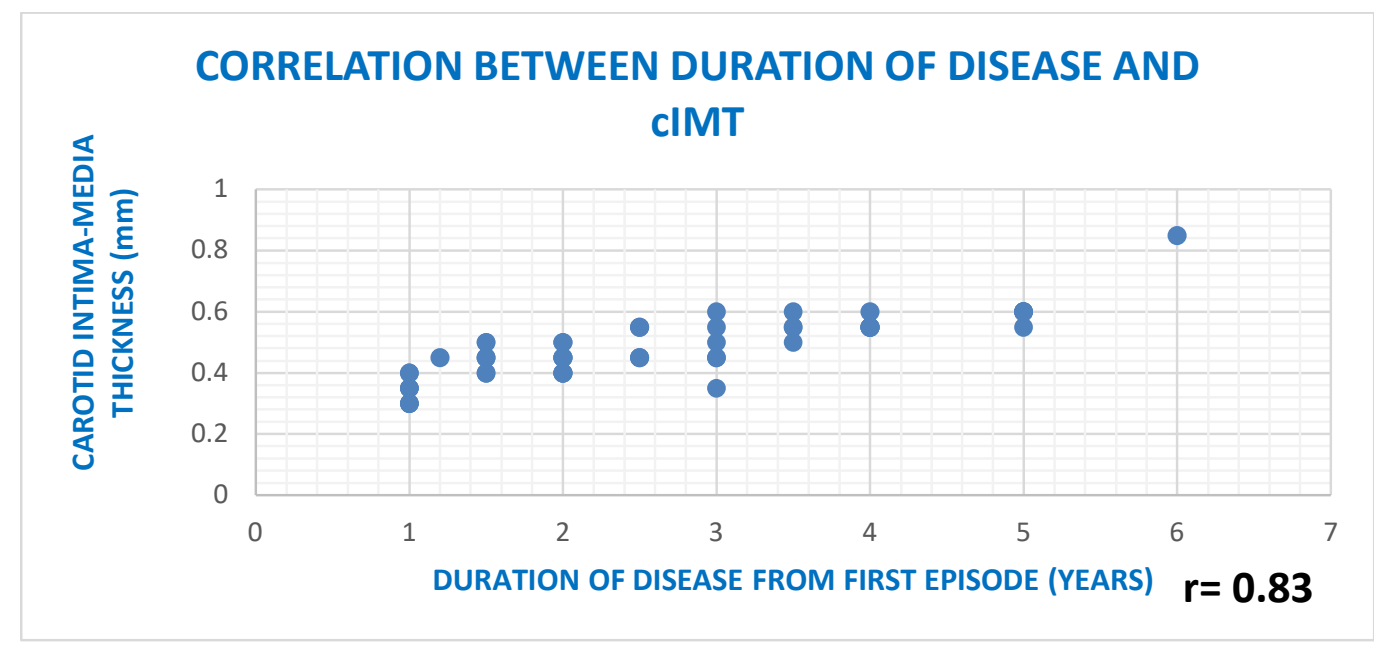

(D) 
Original Research Article

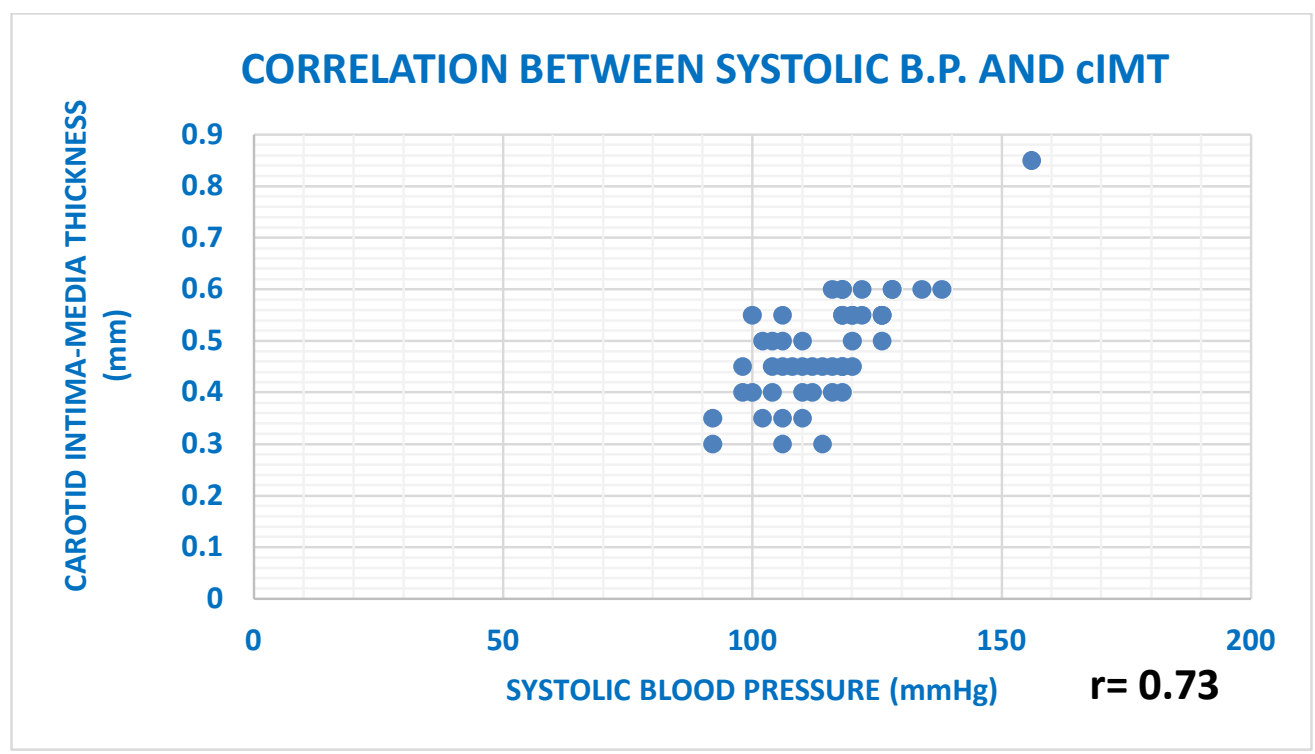

(E)

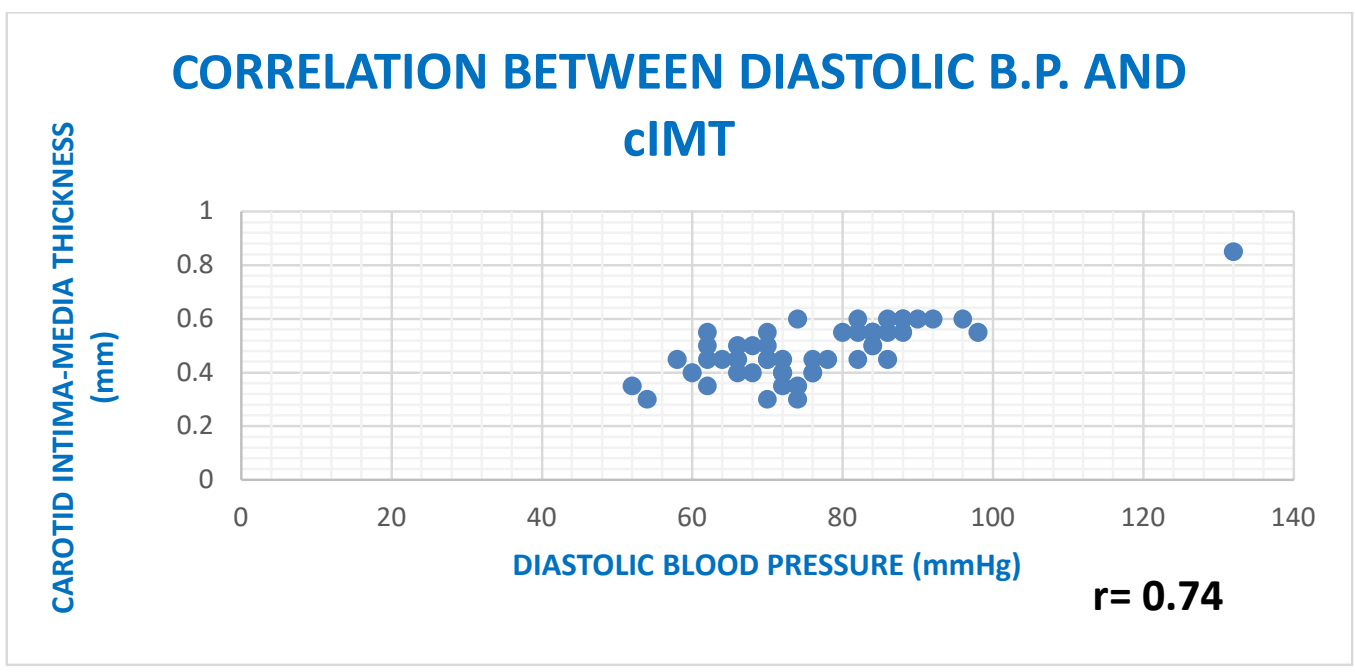

(F)

\section{Discussion}

Intimal Thickening: A Stereotypic Response to Vascular Injury, hyperlipidemia more specifically hypercholesterolemia is a major risk factor for atherosclerosis; even in the absence of other factors, hypercholesterolemia is sufficient to stimulate lesion development [24-28]. The major component of serum cholesterol associated with increased risk is low-density lipoprotein (LDL) cholesterol ("bad cholesterol"); LDL cholesterol is the form of cholesterol that is delivered to peripheral tissues. In contrast, high-density lipoprotein (HDL, "good cholesterol") mobilizes cholesterol from tissue and transports it to the liver for excretion in the bile. Lipids are typically transported in the bloodstream bound to specific apoproteins (forming lipoprotein complexes). Dyslipoproteinemiascan result from mutations that alter the apoproteins or the lipoprotein receptors on cells, [29] or from other disorders that affect the circulating levels of lipids (e.g., nephrotic syndrome, alcoholism, hypothyroidism, or diabetes mellitus) [30] there was similarity of both groups in their basic demographic data, the cIMT was significantly thicker in children with nephrotic syndrome. The cIMT in nephrotic children have strongly correlated with duration of disease and some extent with increased levels of total cholesterol, VLDL, LDL and TGs $(\mathrm{p}<0.05)$. There are limited number of studies available of this thickness value of cIMT in nephrotic children. 
However increase in BMI, SBP and DBP also contribute in increase of cIMT in both groups $(\mathrm{p}<0.05)$. Many studies [32-34] found that increase in body mass index, systolic blood pressure and diastolic blood pressure indirectly related with increase thickness of cIMT in both groups. The level of total cholesterol, LDL, VLDL, homocystein, apoprotein B and A1 were significantly raised in children with idiopathic nephrotic syndrome [36]. cIMT is true marker of evaluation of diffuse thickening and stiffness of large and medium sized vessel. It is secondary to hypertension and atherosclerosis that is focal lesion secondary to hyperlipidemia and metabolic disorder.

Graph (A, B \& C) showed correlation between total serum cholesterol, LDL cholesterol, and serum triglyceride level and cIMT in study group. It was shown that total serum cholesterol, LDL cholesterol, and serum triglyceride level had positive and significant correlation with cIMT. This positive correlation was also found by other authors [34, 36-42].

Graph (D) showed correlation between duration of disease and carotid intima-media thickness. A significant positive correlation was found in the study. Positive correlation was also found in the study done by Nakysa Hooman et al [33].

A positive correlation between duration of disease and cIMT was also present in the study done by Mona $\mathrm{H} \mathrm{El}$ Samahy et al [43], but the disease was not nephrotic syndrome but Type-1 diabetes mellitus in children and adolescents.

Graph (E \& F) shows that in the present study there was a significant positive correlation between systolic blood pressure, diastolic blood pressure and cIMT [ 44- 49].

\section{Conclusion}

Carotid intima-media thickness was thicker in nephrotic children. cIMT were influenced by the factor that increases thickness of cIMT were hyperlipidemia, hypertension, hypoproteinemia and duration of disease.

Disclaimer: The views expressed in this paper are those of the authors and do not necessarily reflect the official position of the institution they are affiliated with.

Abbreviation: $c \mathrm{MMT}=$ carotid intima media thickness, $\mathrm{RBS}=$ Random blood sugar, $\mathrm{LDL}=$ Low density lipoprotein, $\mathrm{VLDL}=$ Very low density lipoprotein, $\mathrm{TGs}=$ Total triglycerides and $\mathrm{BMI}=$ Body mass index .
Funding: Nil, Conflict of interest: None initiated, Perission from IRB: Yes

\section{References}

1. Grimm RH Jr, Svendsen KH, Kasiske B, Keane WF, Wahi MM. Proteinuria is a risk factor for mortality over 10 years of follow-up. MRFIT Research Group. Multiple Risk Factor Intervention Trial. Kidney Int Suppl. 1997 Dec; 63:S10-4.

2. Portman RJ, HawkinsE, Verani R. Premature atherosclerosis in pediatric renal patients : report of the southest pediatric Nephrology study Group. Pediatr Nephrol 1991; 4: 1-10.

3. Dirisamer A, Hachemian N, Bucek RA, Wolf F, Reiter M, Widhalm K. The effect of low-dose simvastatin in children with familial hypercholesterolaemia: a 1-year observation. Eur J Pediatr. 2003 Jun; 162(6):421-5. Epub 2003 Mar 15.

4. Matsushima H, Yamasaki Y, NaoK, Kawamori R, Kamada T. Ultrasonographic measurement of the carotid artery wall thickness in diabetic patients (in Japanese). J Jpn Diabetes Soc 1990; 3: 941-45.

5. Spencer MP, Reid JM. Quantitation of carotid stenosis with continuous-wave (C-W) Doppler ultrasound. Stroke. 1979 May-Jun;10(3):326-30.

6. Litwin M, Niemirska A. Intima-media thickness measurements in children with cardiovascular risk factors. Pediatr Nephrol. 2009 Apr; 24(4):707-19. doi: 10. 1007 /s00467-008-0962-3. Epub 2008 Sep 11.

7. Lorenz MW, Markus HS, Bots ML, Rosvall M, Sitzer M. Prediction of clinical cardiovascular events with carotid intima-media thickness: a systematic review and meta-analysis. Circulation. 2007 Jan 30;115 (4):459-67. Epub 2007 Jan 22

8. Wang JG, Staessen JA, Li Y, Van Bortel LM, Nawrot T, Fagard R, Messerli FH, Safar M. Carotid intimamedia thickness and antihypertensive treatment: a metaanalysis of randomized controlled trials. Stroke. 2006 Jul; 37(7):1933-40. Epub 2006 Jun 8.

9. Tkaczyk M, Czupryniak A, Owczarek D, Lukamowicz J, Nowicki M. Markers of endothelial dysfunction in children with idiopathic nephrotic syndrome. Am J Nephrol. 2008; 28(2):197-202. Epub 2007 Oct 24. 
10. Leno C, Pascual J, Polo JM, Berciano J, Sedano C. Nephrotic syndrome, accelerated atherosclerosis, and stroke. Stroke. 1992 Jun;23(6):921-2.

11. Hopp L, Gilboa N, Kurland G, Weichler N, Orchard TJ. Acute myocardial infarction in a young boy with nephrotic syndrome: a case report and review of the literature. Pediatr Nephrol. 1994 Jun; 8(3):290-4.

12. Kniazewska MH, Obuchowicz AK, Wielkoszyn'ski T, Zmudzin'ska-Kitczak J, Urban K, Marek M, et al. Atherosclerosis risk factors in young patients formerly treated for idiopathic nephrotic syndrome. Pediatr Nephrol 2009;24:549-54.

13. Ksiazek J, Niemirska A, Lipka M, Grenda R. [Evaluation of arterial intima-media thickness (IMT) in children with idiopathic nephrotic syndrome-preliminary report]. Przegl Lek. 2006;63 Suppl 3:205-7.

14. Tang R, Hennig M, Thomasson B, Scherz R, Ravinetto R, Catalini R, Rubba P, Zanchetti A, Bond MG. Baseline reproducibility of B-mode ultrasonic measurement of carotid artery intima-media thickness: the European Lacidipine Study on Atherosclerosis (ELSA). J Hypertens. 2000 Feb;18(2):197-201.

15. Bots ML, Hoes AW, Koudstaal PJ, Hofman A, Grobbee DE. Common carotid intima-media thickness and risk of stroke and myocardial infarction: the Rotterdam Study. Circulation. 1997 Sep 2; 96 (5): 1432-7.

16. Ludwig M, von Petzinger-Kruthoff A, von Buquoy M, Stumpe KO. [Intima media thickness of the carotid arteries: early pointer to arteriosclerosis and therapeutic endpoint]. Ultraschall Med 2003; 24:162-74. German. Comment in: p. 151-2.

17. Howard G, Sharrett AR, Heiss G, Evans GW, Chambless LE, Riley WA; Carotid artery intimalmedial thickness distribution in general populations as evaluated by B-mode ultrasound. ARIC investigators. Stroke 1993; 24:1297-304.

18. Poredos P. Intima-media thickness: indicator of cardiovascular risk and measure of the extent of atherosclerosis. Vasc Med. 2004 Feb; 9(1):46-54.

19. Bots ML, Grobbee DE. Intima media thickness as a surrogate marker for generalised atherosclerosis. Cardiovasc Drugs Ther. 2002 Jul;16(4):341-51.
20. Hulthe J, Wikstrand J, Emanuelsson H, Wiklund O, de Feyter PJ, Wendelhag I. Atherosclerotic changes in the carotid artery bulb as measured by B-mode ultrasound are associated with the extent of coronary atherosclerosis. Stroke. 1997 Jun;28(6):1189-94.

21. Taylor AJ, Kent SM, Flaherty PJ, Coyle LC, Markwood TT, Vernalis MN. ARBITER: Arterial Biology for the Investigation of the Treatment Effects of Reducing Cholesterol: a randomized trial comparing the effects of atorvastatin and pravastatin on carotid intima medial thickness. Circulation. 2002 Oct 15;106 (16):2055-60.

22. ISKDC: The primary nephrotic syndrome in children. Identification of patients with minimal change nephrotic syndrome from initial response to prednisone, J Pediatr 98 (4):561-64, 1981.

23. Niaudet P: Steroid-resistant idiopathic nephrotic syndrome in children. In Avner ED, Harmon WE, Niaudet P, editors: Pediatric nephrology, Philadelphia, 2004, Lippincott Williams \& Wilkins.

24. Perk J, De Backer G, Gohlke H, Graham I, Reiner Z, Verschuren M, Albus C, Benlian P, Boysen G, Cifkova R, Deaton C, Ebrahim S, Fisher M, Germano G, Hobbs R, Hoes A, Karadeniz S, Mezzani A, Prescott E, Ryden L, Scherer M, Syvänne M, Scholte op Reimer WJ, Vrints C, Wood D, Zamorano JL, Zannad F; European Association for Cardiovascular Prevention \& Rehabilitation (EACPR); ESC Committee for Practice Guidelines (CPG). European Guidelines on cardiovascular disease prevention in clinical practice (version 2012). The Fifth Joint Task Force of the European Society of Cardiology and Other Societies on Cardiovascular Disease Prevention in Clinical Practice (constituted by representatives of nine societies and by invited experts). Eur Heart J. 2012 Jul;33(13):1635-701. doi: 10.1093/eurheartj/ehs092. Epub 2012 May 3.

25. Mancia G, Fagard R, Narkiewicz K, et al. 2013 $\mathrm{ESH} / \mathrm{ESC}$ guidelines for the management of arterial hypertension: the Task Force for the Management of Arterial Hypertension of the European Society of Hypertension (ESH) and of the European Society of Cardiology (ESC). Eur Heart J. 2013 Jul;34(28):2159219. doi: 10.1093/eurheartj/eht151. Epub 2013 Jun 14.

26. Stein JH, Korcarz CE, Hurst RT, etal. American Society of Echocardiography Carotid Intima-Media Thickness Task Force. Use of carotid ultrasound to 
identify subclinical vascular disease and evaluate cardiovascular disease risk: a consensus statement from the American Society of Echocardiography Carotid Intima-Media Thickness Task Force. Endorsed by the Society for Vascular Medicine. J Am Soc Echocardiogr. 2008 Feb;21(2):93-111; quiz 189-90. doi: 10.1016/j. echo.2007.11.011.

27. Greenland P, Alpert JS, Beller GA, etal. American College of Cardiology Foundation; American Heart Association. 2010 ACCF/AHA guideline for assessment of cardiovascular risk in asymptomatic adults: a report of the American College of Cardiology Foundation/American Heart Association Task Force on Practice Guidelines. J Am Coll Cardiol. 2010 Dec 14;56 (25):e50-103. doi: 10.1016/j.jacc.2010.09.001.

28. Goff DC Jr, Lloyd-Jones DM, Bennett G, et al. American College of Cardiology /American Heart Association Task Force on Practice Guidelines. 2013 ACC /AHA guideline on the assessment of cardiovascular risk: a report of the American College of Cardiology/American Heart Association Task Force on Practice Guidelines. J Am Coll Cardiol. 2014 Jul 1;63(25 Pt B):2935-59. doi: 10.1016/j.jacc.2013.11.005. Epub 2013 Nov 12.

29. Gonzalez J, Wood JC, Dorey FJ, Wren TA, Gilsanz V. Reproducibility of carotid intima-media thickness measurements in young adults. Radiology. 2008 May; 247 (2):465-71. doi: 10.1148/radiol.2472070691. Epub 2008 Mar 18

30. Luo X, Yang Y, Cao T, Li Z. Differences in left and right carotid intima-media thickness and the associated risk factors. Clin Radiol. 2011 May; 66(5):393-8. doi: 10.1016/j.crad.2010.12.002. Epub 2011 Feb 15.

31. Srivastava RN, Mayekar G, Anand R, Choudhry VP, Ghai OP, Tandon HD. Nephrotic syndrome in indian children. Arch Dis Child.1975Aug;50(8):626-30.

32. Farida Ahmed Farid, Ahmed Abdullah Mohammed, Hanaa Mohammed Afifi, and Rania Saleh Beltagi; Tissue factor pathway inhibitor in paediatric patients with nephrotic syndrome: SAJCH. 2011 Dec; 5 (4):107111.

33. Nakysa Hooman, Roya isa-Tafreshi, Hasan Otukesh, Seyed-Hassan Mostafavi, Farideh Hallaji; carotid Artery Function in Children with Idiopathic Nephrotic Syndrome: Nefrologia (English Version)
2013; 33:650-6 doi:10.3265/ Nefrologia. pre2013. May. 12036.

34.Tkaczyk M, Czupryniak A, Owczarek D, Lukamowicz J, Nowicki M. Markers of endothelial dysfunction in children with idiopathic nephrotic syndrome. Am J Nephrol 2008;28:197-202.

35. Dnyanesh DK, Suma Dnyanesh, Varadaraj Shenoy. A Study of Serum Lipids in Nephrotic Syndrome in Children. IOSR Journal of Dental and Medical Sciences (IOSR-JDMS) e-ISSN: 2279-0853, p-ISSN: 2279-0861. Volume 13, Issue 3 Ver. I. (Mar. 2014), PP 01-06 available from:www.iosrjournals.org

36. Meltem Dinleyici, Bilal Yildiz, Nuran Çetin, Nurdan Kural, Ozkan Alatas; Serum and urinary leptin and ghrelin in children with nephrotic syndrome: Neuroendocrinol Lett.Vol. 34 2013; 34(5):388-394 available online: http://node.nel.edu

37. Lorenz MW, Markus HS, Bots ML, Rosvall M, Sitzer M. Prediction of clinical cardiovascular events with carotid intima-media thickness: a systematic review and meta-analysis. Circulation 2007;115:459-67.

38. Sarama Saha, Chandan Sarkar, Subhash Chandra Biswas and R Karim; correlation between serum lipid profile and carotid intima-media thickness in polycystic ovarian syndrome. Indian Journal of Clinical Biochemistry, 2008 / 23 (3) 262-266.

39. Kniazewska MH, Obuchowicz AK, Wielkoszy_ski T, Zmudzi ¿ska-Kitczak J, Urban K, Marek M, Atherosclerosis risk factors in young patients formerly treated for idiopathic nephrotic syndrome. Pediatr Nephrol 2009; 24:549-54. [Pubmed]

40. Niaudet $P$, Boyer O. Idiopathic nephrotic syndrome in children: clinical aspects. In: Avner ED, Harmon WE, Niaudet $\mathrm{P}$, Yoshikawa $\mathrm{N}$ (eds.). Pediatric Nephrology. Berlin Heidelberg: Springer-Verlag; 2009. p. 667-702.

41. Falgun Gosai, Hetal Patel;Relationship Between Carotid Intima Media Thickness And Lipid Profile In Type Two Diabetes Mellitus And Stage 2 Hypertension; NJIRM 2014; Vol. 5(2). March-April eISSN: 09759840 pISSN: $2230-9969$.

42. Mona H El Samahy, Randa M Matter, Omneya I Youssef, Manal A Shams El Din El Telbany and 
Nermeen A Kamal; Relation between carotid intima media thickness and oxidative stress markers in type 1 diabetic children and adolescents; J Diabetes Metab Disord. 2013; 12: 50. Published online 2013 Dec 19. doi: $10.1186 / 2251-6581-12-50$

43. F.L. Plavnik, S. Ajzen, O. Kohlmann Jr., A. Tavares, M.T. Zanella, A.B. Ribeiro and O.L. Ramos; Intima-media thickness evaluation by B-mode ultrasound. Correlation with blood pressure levels and cardiac structures; Braz J Med Biol Res, January 2000, Volume 33(1) 55-64.

44. Jonathan M. Sorof, Andrei V. Alexandrov, Gina Cardwell, Ronald J. Portman;Carotid Artery IntimalMedial Thickness and Left Ventricular hypertrophy in Children With Elevated Blood Pressure: January 2003, VOLUME 111 / ISSUE 1.

45. Marc B. Lande, Nancy L. Carson, Jason Roy, Cecilia C. Meagher; Effects of Childhood Primary Hypertension on Carotid Intima Media Thickness A Matched Controlled Study.; (Hypertension. 2006;48:4044.) available from: https://doi.org/10.1161/01.HYP. 0000227029. 10536.e8
46. Schiel R, Beltschikow W, Radón S, Kramer G, Perenthaler T, Stein G; increased carotid intimamedia thickness and associations with cardiovascular risk factors in obese and overweight children and adolescents. European Journal of Medical Research [2007, 12(10):503-508].

47. Stella Stabouli, VasiliosKotsis, Christina Karagianni, Nikos Zakopoulos, Andreas Konstantopoulos; Blood Pressure and Carotid Artery IntimaMedia Thickness in Children and Adolescents: The Role of Obesity, Hellenic J Cardiol 2012; 53: 41-47 available from: http://www.hellenicjcardiol.org /archive /full_text/2012/1/2012_1_41.pdf

48. Nicole L. Spartano,Jacqueline A. Augustine, Wesley K. Lefferts, Brooks B. Gump, Kevin S. Heffernan. The relationship between carotid blood pressure reactivity to mental stress and carotid intimamedia thickness October 2014, Volume 236, Issue 2, Pages 227-229; DOI: http: //dx.doi.org/10. 1016/j. atherosclerosis.2014.07.014

49. Sorof JM, Cardwell G, Franco K, Portman $\mathrm{RJ}$;Ambulatory blood pressure and left ventricular mass index in hypertensivechildren,Hypertension. 2002Apr; 39(4):903-8.

\section{How to cite this article?}

Chaubey S, Singh Vijay K, Singh P, Mittal M, Singh Abhishek K, Kushwaha K.P. A study on intima- media thickness of carotid artery in children with nephrotic syndrome: a cross sectional study. J PediatrRes.2017;4(02):8999.doi:10.17511/ijpr.2017.i02.01. 